\title{
PENGENALAN TOKOH PAHLAWAN PADA UANG KERTAS EDISI 2014 BERBASIS AUGMENTED REALITY
}

\author{
${ }^{1}$ Ardi Wijaya, ${ }^{2}$ Dinda Putri \\ ${ }^{1,2}$ Universitas Muhammadiyah Bengkulu, Indonesia \\ Iardiwijaya@umb.ac.id; 2dindaputri100169@gmail.com
}

\section{Article Info}

Article history:

Received, 24/08/2021

Revised, 08/09/2021

Accepted, 29/10/2021

\section{Kata Kunci:}

AugmentedReality, Pahlawan Nasional, Android.

Keywords:

Augmented Reality, National Hero, Android.

\begin{abstract}
ABSTRAK
Pelajaran sejarah diindonesia sudah diajarkan sejak tingkat Sekolah Dasar (SD), salah satu materi yang diajarkan yaitu mengenai tokoh pahlawan nasional yang sangat berjasa pada bangsa Indonesia yang mana beberapa gambar tokoh pahlawan diabadikan pada uang kertas Indonesia. Namun dengan metode pembelajaran hanya menggunakan buku cetak disertai metode ceramah yang cenderung membuat siswa bosan dan cepat merasa kantuk, maka media pembelajaran yang menarik juga sangat diperlukan. Oleh karena itu, dibangun sebuah aplikasi berbasis android menggunakan teknologi Augmented Reality dengan menjadikan uang kertas sebagai marker yang mana aplikasi ini terdapat animasi 3D tokoh pahlawan serta sejarahnya dan mengeluarkan audio. Metodelogi pengembangan aplikasi ini menggunakan model Incremental yang terdiri dari 4 tahap yaitu : Analysis, design, code, dan testing. Berdasarkan hasil kuesioner menunjukkan hasil Sangat Tidak Setuju 0\%, Tidak Setuju 0\%, Setuju 43\%, dan Sangat Setuju $57 \%$. Hasil ini menunjukkan secara keseluruhan yang terdapat pada system berjalan dengan baik, dan layak digunakan.
\end{abstract}

\begin{abstract}
History lessons in Indonesia are taught starting from Elementary School $(S D)$ level. One of materials taught in elementary schools is a national hero figure who has greatly contributed to Indonesian nation. Several images of heroes were immortalized on Indonesian banknotes. The learning method that is carried out only with printed books and lectures tends to make students bored and quickly feel sleepy. In a site like this, interesting learning media is needed. This study seeks to build an android-based application using Augmented Reality technology, using banknotes as markers to produce $3 D$ animation applications that speak about heroes and their historical backgrounds. This application development methodology uses an Incremental model which consists of 4 stages, namely: Analysis, design, code, and testing. Distributed questionnaires get results; Strongly Disagree $=0 \%$, Disagree $=0 \%$, Agree $=43 \%$, and Strongly Agree $=57 \%$. These results indicate that the overall system is running well and feasible to use.
\end{abstract}

This is an open access article under the CC BY-SAlicense.

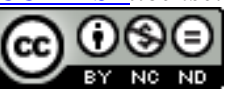

\section{Penulis Korespondensi:}

Dinda Putri,

Program Studi Teknik Informatika,

Universitas Muhammadiyah Bengkulu,

Email: dindaputri100169@gmail.com

\section{PENDAHULUAN}

Pelajaran Sejarah di Indonesia sudah mulai diajarkan sejak tingkat Sekolah Dasar (SD), Materi yang diajarkan salah satunya mengenai para tokoh Pahlawan Nasional.[1] Menurut Kamus Besar Bahasa Indonesia, pahlawan adalah orang yang menonjol karena keberaniannya dan pengorbanannya dalam membela kebenaran, atau pejuang yang gagah berani. Berkat perjuangan yang gagah berani, sebagai bentuk penghormatan pahlawan diabadikan gambarnya di dalam uang kertas Indonesia sesuai dengan Undang - undang No.7 tahun 2011 Pasal 7 ayat (1) yang berbunyi “ Gambar pahlawan nasional dan/atau Presiden dicantumkan sebagai gambar utama pada bagian depan Rupiah “'. 
Penyampaian materi sejarah pada pengenalan tokoh pahlawan Indonesia khususnya di kelas 5 Sekolah Dasar Negeri 132 Bengkulu Utara, selama ini hingga sekarang hanya dengan cara mendengarkan penjelasan dari Guru dan media buku cetak saja. Mengingat rendahnya minat baca siswa informasi tokoh pahlawan dalam bentuk buku cetak cenderung membuat siswa cepat merasa bosan dan menyebabkan kemauan belajar siswa berkurang. Oleh karena itu, diperlukan alternatif media pembelajaran yang lebih menarik untuk meningkatkan minat belajar siswa.

Perkembangan gadget terutama smartphone dapat dijadikan alternatif media pembelajaran mengenai pengenalan tokoh pahlawan dengan lebih menarik dan efektif menggunakan aplikasi berteknologi Augmented Reality. Augmented Reality (AR) adalah teknologi yang dapat menggabungkan benda maya dua dimensi (2D) dan ataupun tiga dimensi (3D) ke dalam sebuah lingkungan nyata lalu memproyeksikan benda-benda maya tersebut dalam waktu nyata (real time) [2]Aplikasi Pengenalan Tokoh Pahlawan Nasional dengan menggunakan Augmented Reality berbasis android adalah aplikasi yang memanfaatkan kamera pada smartphone dan uang kertas rupiah sebagai marker, dan dioperasikan dengan 2 cara mengarahkan kamera ke uang kertas, kemudian akan muncul animasi 3D dan dapat mengeluarkan audio tentang pengenalan tokoh pahlawan yang terdapat pada uang tersebut.

Dibangun aplikasi Pengenalan tokoh pahlawan pada uang kertas ini dengan tujuan agar media pembelajaran ini dapat memudahkan dan menambah semangat belajar siswa dalam mengenal Tokoh Pahlawan Indonesia yang lebih interaktif, praktis, menarik dan efisien.

\section{A. Augmented Reality}

Augmented reality (AR) merupakan penggabungan benda-benda nyata dan maya di lingkungan nyata, berjalan secara interaktif dalam waktu nyata, dan terdapat integrasi antar benda dalam tiga dimensi, yaitu benda maya terintegrasi dalam dunia nyata[3]. Penggabungan benda nyata dan maya dimungkinkan dengan teknologi tampilan yang sesuai, interaktivitas dimungkinkan melalui perangkat-perangkat input tertentu, dan integrasi yang baik memerlukan penjejakan yang efektif [4]

Augmented Reality membuat eksplisit menjadi implisit; ini berarti bahwa informasi yang tersirat terkait dengan konteks dibuat dapat digunakan dan dapat diakses langsung melalui antarmuka AR. [5]

Metode pada Augmented reality dapat dibagi menjadi tiga yaitu:

1) Marker Based Tracking.

2) Markerless Augmented Reality. [6]

\section{B. Pahlawan Nasional}

Pahlawan Nasional adalah gelar yang diberikan kepada warga negara Indonesia yang berjuang melawan penjajahan yang gugur demi membela bangsa dan negara Indonesia, atau menghasilkan prestasi dan karya yang luar biasa bagi pembangunan dan kemajuan bangsa dan negara Republik Indonesia.Berkat perjuangan yang sangat heroik, Pahlawan Nasional diabadikan gambarnya di dalam uang kertas Indonesia. Namun banyak masyarakat yang tidak mengetahui sejarah dari para Pahlawan Nasional yang terdapat pada uang kertas tersebut. Masyarakat Indonesia hanya menggunakan uang sebagai alat jual beli saja. [7]

\section{Uang}

Uang secara umum adalah sesuatu yang dapat diterima secara umum sebagai alat pembayaran dalam suatu wilayah tertentu atau sebagai alat pembayaran utang, ataa sebagai alat untuk melakukan pembelian barang atau jasa. Dengan kata lain, uang merupakan suatu alat yang dapat digunakan dalam suatu wilayah tertentu. [8]

\section{Android}

Pada penelitiannya menjelaskan bahwa, Android adalah sistem operasi berbasis Linux yang dirancang untuk perangkat bergerak layar sentuh seperti telepon pintar dan komputer tablet. 
Android awalnya dikembangkan oleh Android, Inc dengan dukungan finansial Google, yang kemudian membelinya pada tahun 2005. [9]

\section{E. Blender}

Blender merupakan software pengolah 3 dimensi (3D) untuk membuat animasi 3D, yang bisa dijalankan di windows, macintosh dan linux. Blender juga sama seperti software $3 D$ pada umumnya seperti 3DS Max, maya dan lightwave, tetapi juga mempunyai perbedaan yang cukup mendasar seperti projek kerja di blender bisa dikerjakan dihampir semua software 3D komersial lainnya, tampilannya yang bisa diatur sesuka hati, mempunyai simulasi physics yang baik dan menggunakan uv yang lebih mudah. Blender juga dapat membuat game karena memilik Game Engine.[10]

\section{F. Unity $3 D$}

Unity $3 D$ adalah sebuah game engine yang berbasis cross-platform. Unity dapat digunakan untuk membuat sebuah game yang bisa digunakan pada perangkat komputer, ponsel pintar android, iPhone, PS3, dan bahkan X-BOX. Unity adalah sebuah sebuah tool yang terintegrasi untuk membuat game, arsitektur bangunan dan simulasi.[11] Untuk menghasilkan game multiplatform, untuk setiap platform, semua pengaturan berbeda dari sistem harus dapat dikendalikan. Dalam makalah ini, penggunaan mesin Unity3D diusulkan berdasarkan alasan mengapa kode dapat ditulis dengan C\#, JavaScript dan Boo, Unity3D engine dikembangkan sebagai kode berbasis C\#- dan Mono [12].

\section{G. Vuforia}

Vuvoria adalah Augmented Reality Software Development Kit (SDK) untuk perangkat mobile yang memungkinkan pembuatan aplikasi AR. SDK Vuforia juga tersedia untuk digabungkan dengan Unity yaitu bernama Vuforia AR Extension for Unity. Vuforia merupakan SDK yang disediakan oleh Qualcomm untuk membantu para developer membuat aplikasi-aplikasi Augmented Reality (AR) di mobile phones (iOS, Android) AR.[13]. Vuforia SDK adalah kit pengembangan perangkat lunak AR untuk seluler perangkat yang diluncurkan oleh Qualcomm. Ini menggunakan visi computer teknologi untuk mengenali dan menangkap gambar planar atau 3D objek secara real time dan memungkinkan pengembang menempatkan virtual objek melalui jendela bidik kamera dan menyesuaikan posisi objek di latar belakang kamera. [14]

\section{H. Unifed Modeling Language (UML)}

UML merupakan suatu kumpulan teknik terbaik yang telah terbukti sukses dalam memodelkan system yang besar dan kompleks. UML tidak hanya digunakan dalam proses pemodelan perangkat lunak, namun hampir dalam semua bidang yang membutuhkan pemodelan.[15]

Perancangan perangkat lunak ini menggunakan metode Incremental dengan menggunakan 4 diagram UML yaitu : Use Case Diagram, Class Diagram, Activity Diagram, dan Sequence Diagram.

\section{METODE PENELITIAN}

\subsection{Metode Pengembangan Sistem}

Dalam penelitian ini pengembangan sistem ini dilakukan dengan menggunakan model incremental, incremental gabungan elemen dari waterfall model dengan spiral model yang keduanya sama-sama sebuah gaya yang iterative. Incremental terdiri dari masing-masing urutan linear yang akan menghasilkan pencapaian perangkat lunak yang sesuai secaraterpisah. Model ini terdiri dari proses analisis, desain, kode dan pengujian/testing [16] .

\subsection{Analisis}

Analisis adalah tahapan awal yang dilakukan pada incremental model yakni penentuan kebutuhan atau analisis kebutuhan. [17] Disini peneliti menggunakan 3 metode yakni : metode observasi yang dilakukan langsung ke SDN 132 Bengkulu Utara, metode studi pustaka untuk 
JSAI : Journal Scientific and Applied Informatics

Vol. 4, No. 3, November 2021, hal. 311 321

E-ISSN: 2614-3054; P-ISSN: 2614-3062, Terkareditasi Kemenristekdikti, Sinta 5

mengumpulkan data, dan metode wawancara yang dilakukan langsung kepada wali kelas kelas 5 dan anak-anak murid kelas 5.

\subsection{Desain}

Tahapan Design adalah tahapan merubah requirement yang masih berupa konsep menjadi spesifikasi sistem yang riil.

\section{a. Use Case Diagram}

Use case diagram disini dapat yakini gambaran atau bentuk visualisasi kebiasaan suatu system selama system ini beraktivitas. Yang mengendalikan atau mengontrol kebiasaan system tersebut adalah actor, jadi antara si actor dan use case saling terkait.

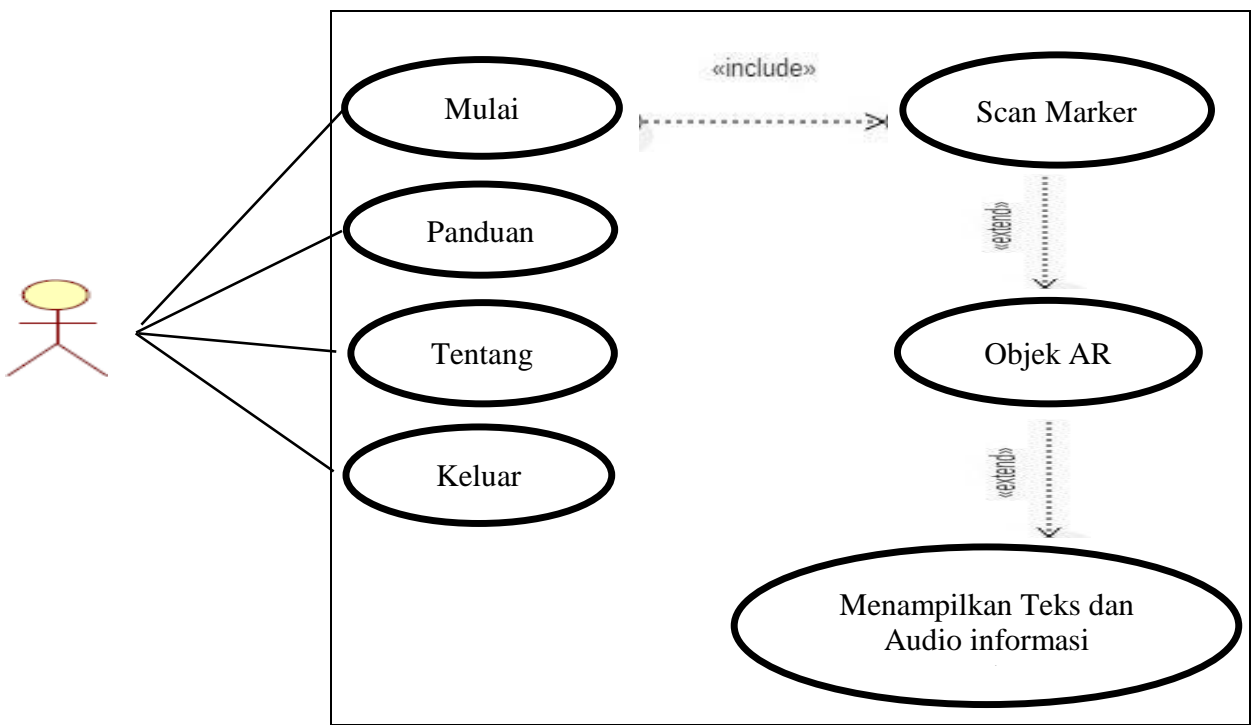

Gambar 1 Use Case Diagram

b. Class Diagram

Class Diagram dibawah ini menggambarkan struktur system dengan menampilkan class, attribute, method dan hubungan antar kelas/objeknya.

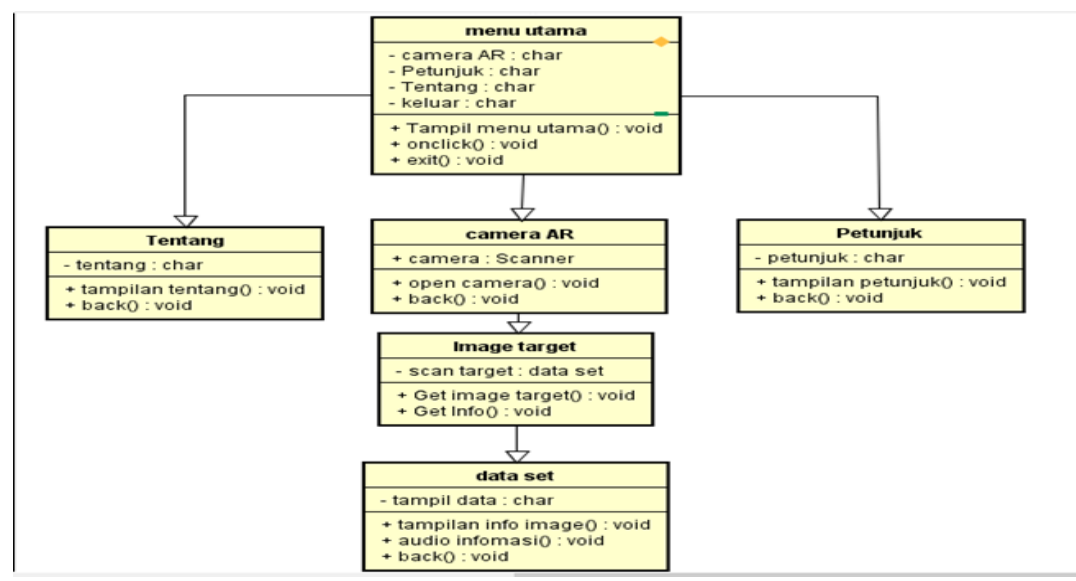

Gambar 2 Class Diagram

c. Activity diagram

Activity diagram menggambarkan berbagai aliran aktivitas dalam system yang dirancang, bagaimana masing-masing fungsionalitas bekerja dan bagaimana suatu fungsionalitas berakhir. [15] 


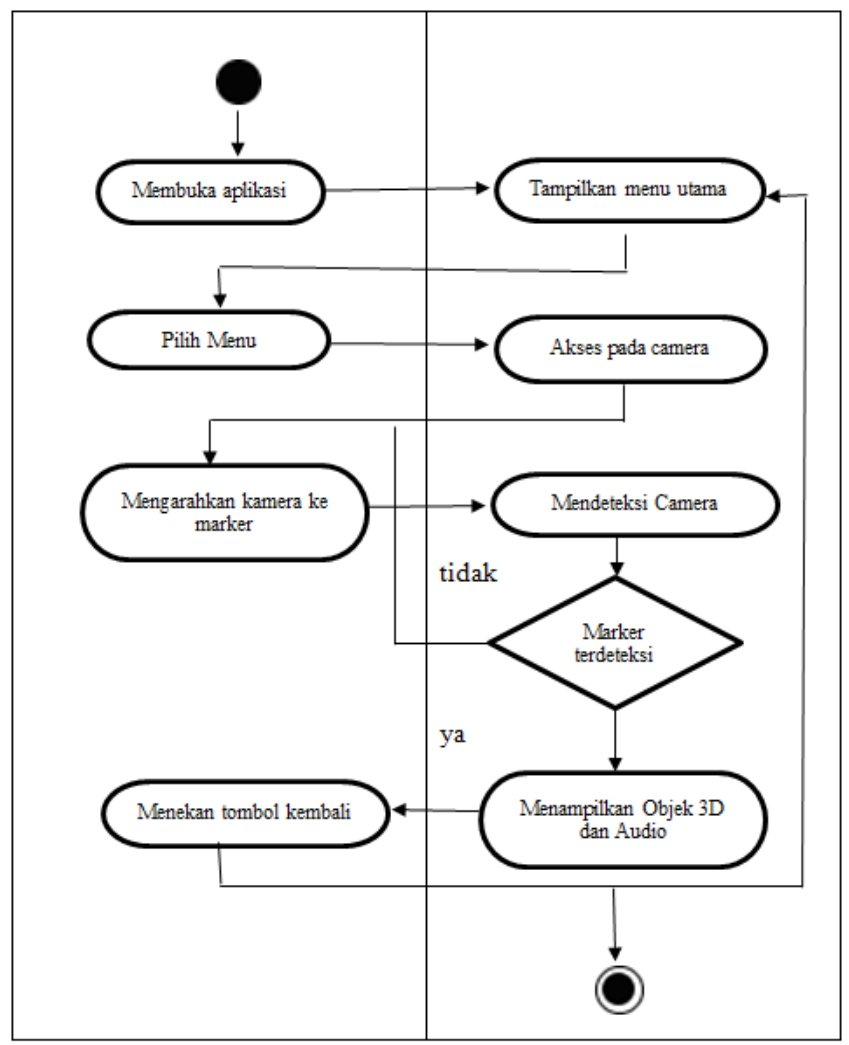

Gambar 3 Activity Diagram

\section{d. Sequence Diagram}

Sequence diagram disini adanya interaksi antar objek didalam sebuah system, interaksi tersebut berupa pesan dan peritah dari objek satu dan pada objek lainnya untuk melakukan sesuatu yang diidnginkan oleh pengguna system. [18]

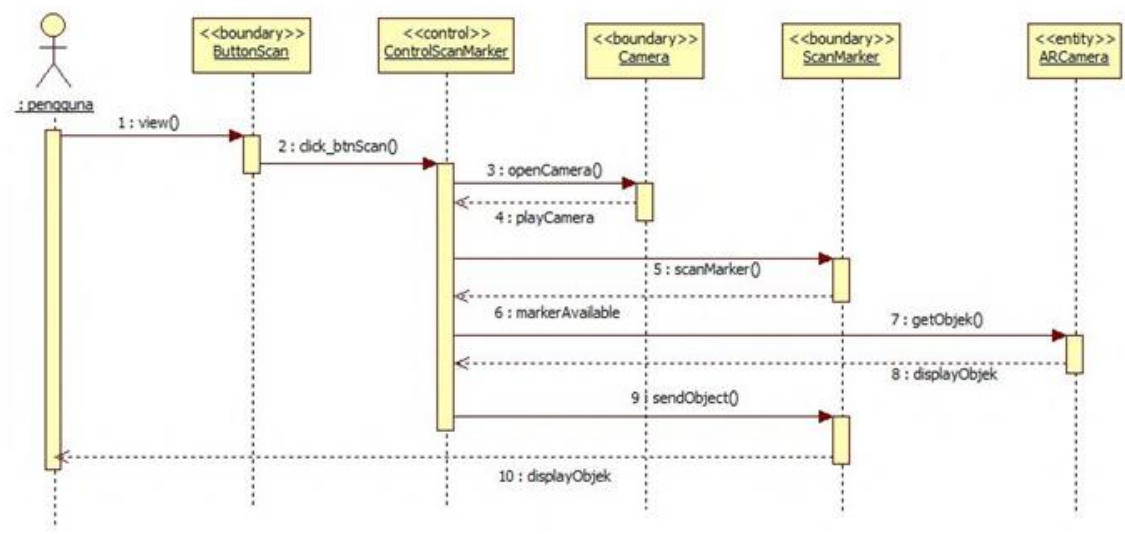

Gambar 4 Sequence Diagram

\section{HASIL DAN ANALISIS}

\subsection{Tampilan-tampilan Aplikasi}

a. Tampilan Interface 


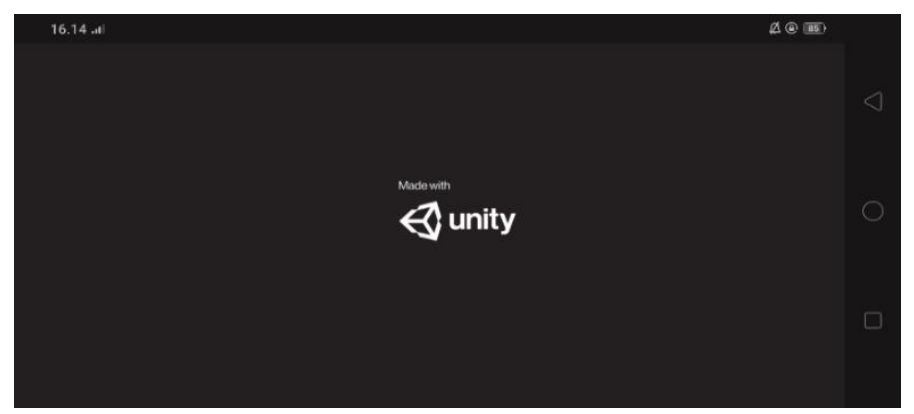

Gambar 5. Tampilan Interface

Ini adalah tampilan interface ketika pertama kali user menjalankan aplikasi.

b. Menu Utama

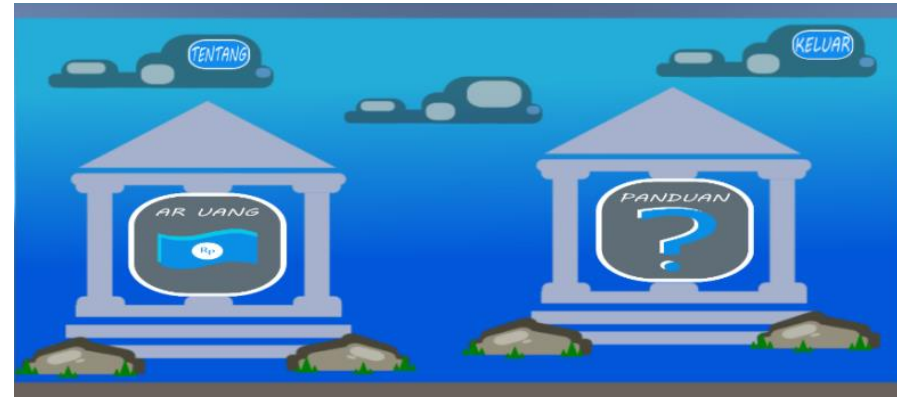

Gambar 6. Tampilan Menu Utama

Ini adalah tampilan menu utama setelah tampilan Interface yang dibahas sebelumnya, Menu utama merupakan tampilan halaman dimana user dapat berinteraksi dengan aplikasi yang tentunya terdapat tombol Mulai, Bantuan, Tentang, dan Keluar dimana setiap tombol mempunyai fungsi sesuai pilihan.

\section{c. Menu Mulai AR}

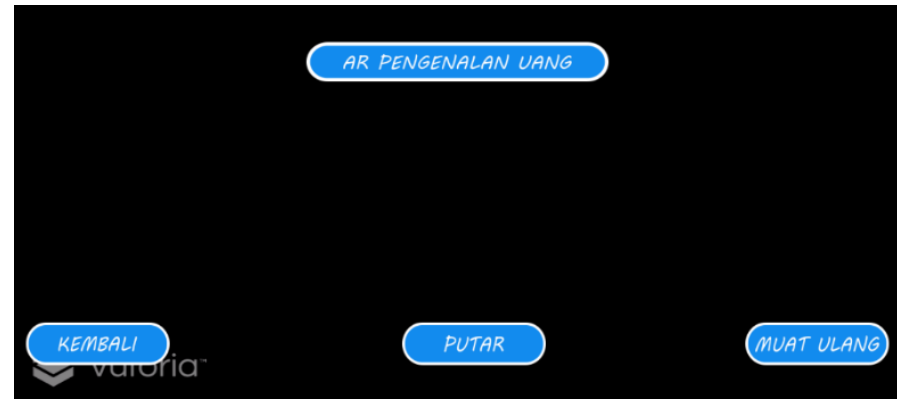

Gambar 7. Tampilan Mulai AR

Ini adalah tampilan menu Mulai AR setelah user mengklik menu mulai pada menu utama, di dalam menu ini kamera langsung menyala dan melakukan scan image target pada marker untuk menampilkan objek 3D sesuai dengan marker yang di scan. Lalu ketika terdeteksi gambar dari marker yang sudah didaftarkan pada system dan system mengenali gambar dari marker tersebut makan system akan memunculkan abjek 3D pada posisi di atas gambar marker pada layar camera. Disini juga terdapat Tombol Suara dan Muat Ulang yang dimana user bisa menghidupkan suara atau mematikan, dan tombol Muat Ulang berfungsi jika user ingin mengscan ulang marker atau menggangti marker yang lainnya.

Berikut adalah salah satu contoh hasil dari aplikasi uang kertas yang berjumlah 7 lembar : 
JSAI : Journal Scientific and Applied Informatics

Vol. 4, No. 3, November 2021, hal. 311 321

E-ISSN: 2614-3054; P-ISSN: 2614-3062, Terkareditasi Kemenristekdikti, Sinta 5

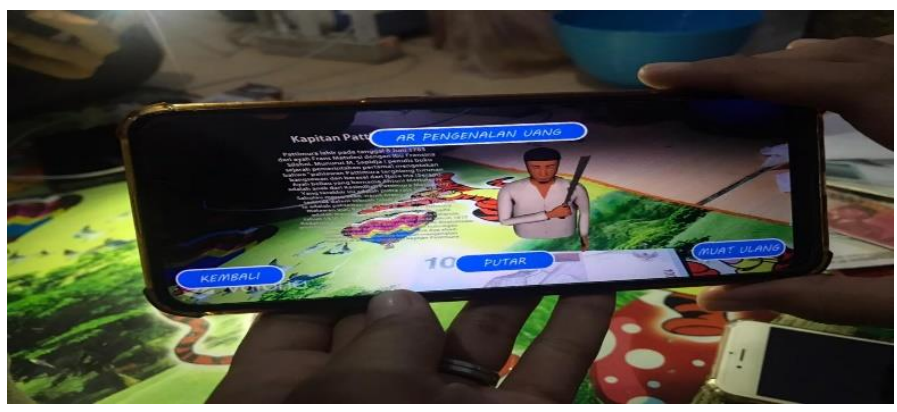

Gambar 8. Marker Uang Kertas Rp. 1.000

d. Menu Panduan

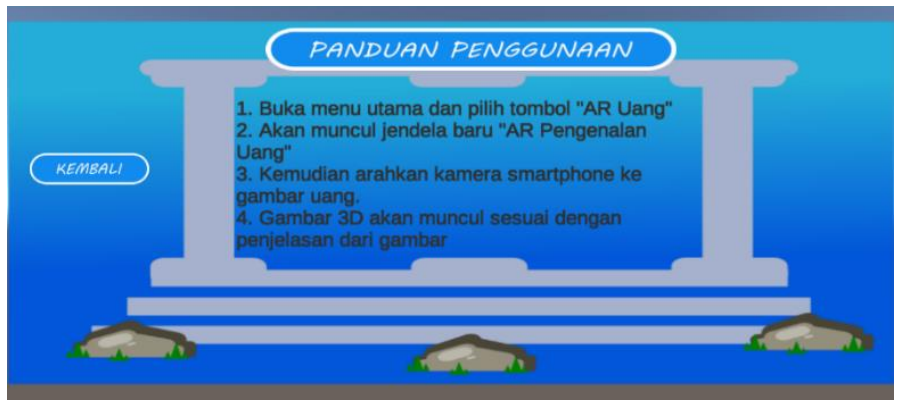

Gambar 9. Tampilan Menu Panduan

Menu Panduan merupakan menu yang menampilkan tatacara menggunakan aplikasi.

e. Menu Tentang

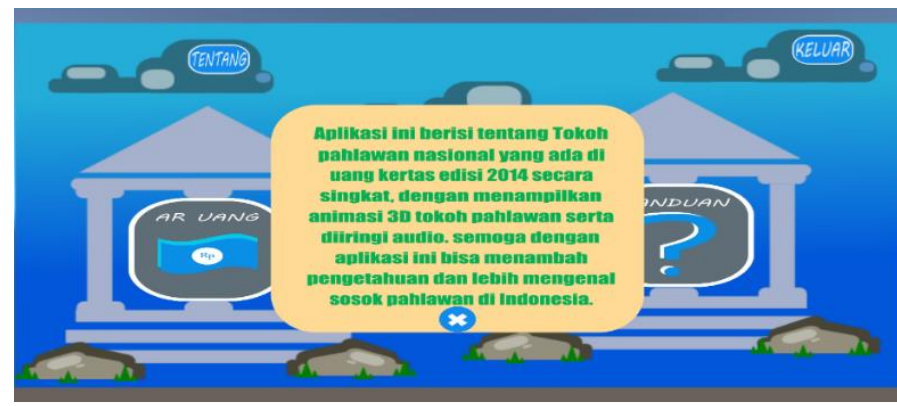

Gambar 10. Tampilan Menu Tentang

Menu tentang merupakan tampilan tentang keterangan aplikasi. Tombol " $\mathrm{X}$ " dibawah digunakan jika user ingin menutup menu Tentang lalu otomatis akan kembali ke menu utama.

f. Menu Keluar 


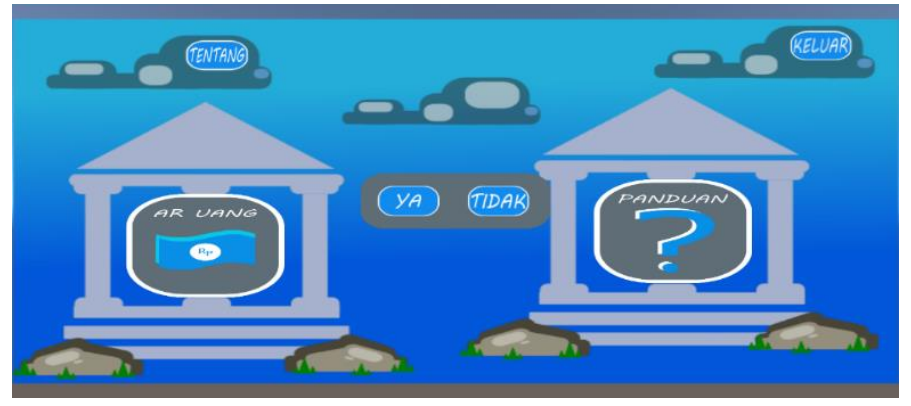

Gambar 11.Tampilan Menu Keluar

Terakhir yaitu menu keluar yang terdapat pada menu utama. Menu ini digunakan jika user ingin keluar dari aplikasi. Setelah user menekan tombol menu keluar maka akan muncul pilihan "Ya / Tidak", jika user menekan tombol Ya maka otomatis menutup atau keluar dari aplikasi dan jika user menekan tombol Tidak maka aplikasi akan menampilkan tampilan sebelumnya.

\section{PENGUJIAN}

\section{a. Black Box}

Pengujian kotak hitam dilakukan berdasarkan kebutuhan pengguna,jadi jika ada yang tidak lengkap atau persyaratan tak terduga dapat dengan mudah diidentifikasi dan dapat diatasi nanti. Pengujian kotak hitam adalah dilakukan berdasarkan perspektif pengguna akhir. Pentingnya pengujian kotak hitam utama menangani keduanya valid dan masukan yang tidak valid dari sudut pandang pengguna[19]. Penulis melakukan tahap pengujian terhadap sistem secara fungsional untuk mengetahui keberhasilan dari implementasi sistem yang telah dilakukan, yaitu dengan menggunakan metode Black Box yang difokuskan pada output yang dihasilkan sistem.[20] Adapun beberapa tahap pengujian yang telah penulis lakukan adalah sebagai berikut

1. Pengujian halaman menu utama

Tabel 1 Pengujian Halaman Menu Utama

\begin{tabular}{|c|l|l|c|}
\hline No. & \multicolumn{1}{|c|}{ Pengujian } & \multicolumn{1}{|c|}{ Hasil yang diharapkan } & Hasil Pengujian \\
\hline 1 & Uji tombol Mulai/AR uang & Halaman Mulai ditampilkan & Valid \\
\hline 2 & Uji tombol Panduan & $\begin{array}{l}\text { Halaman Panduan } \\
\text { ditampilkan }\end{array}$ & Valid \\
\hline 3 & Uji tombol Tentang & $\begin{array}{l}\text { Halaman Tentang } \\
\text { ditampilkan }\end{array}$ & Valid \\
\hline 4 & Uji tombol Keluar & Halaman Keluar ditampilkan & Valid \\
\hline
\end{tabular}

2. Pengujian Black Box Halaman Panduan

Tabel 2 Pengujian Halaman Panduan

\begin{tabular}{|c|c|l|c|}
\hline No. & \multicolumn{1}{|c|}{ Pengujian } & Hasil yang diharapkan & Hasil Pengujian \\
\hline 1 & Uji tombol Panduan & $\begin{array}{l}\text { Halaman Panduan } \\
\text { ditampilkan }\end{array}$ & Valid \\
\hline
\end{tabular}

\section{Pengujian Halaman Tentang}

Tabel 3 Pengujian Halaman Tentang

\begin{tabular}{|c|c|l|c|}
\hline No. & \multicolumn{1}{|c|}{ Pengujian } & Hasil yang diharapkan & Hasil Pengujian \\
\hline 1 & Uji tombol Tentang & $\begin{array}{l}\text { Halaman Tentang } \\
\text { ditampilkan }\end{array}$ & Valid \\
\hline
\end{tabular}

4. Pengujian Halaman KeluarS 
JSAI : Journal Scientific and Applied Informatics

Vol. 4, No. 3, November 2021, hal. 311 321

E-ISSN: 2614-3054; P-ISSN: 2614-3062, Terkareditasi Kemenristekdikti, Sinta 5

Tabel 4 Pengujian Halaman Keluar

\begin{tabular}{|l|l|l|c|}
\hline No. & \multicolumn{1}{|c|}{ Pengujian } & \multicolumn{1}{|c|}{ Hasil yang diharapkan } & Hasil Pengujian \\
\hline 1 & Uji Tombol Ya & Keluar dari aplikasi & Valid \\
\hline 2 & Uji Tombol Tidak & $\begin{array}{l}\text { Halaman Menu Utama } \\
\text { ditampilkan }\end{array}$ & Valid \\
\hline
\end{tabular}

5. Pengujian Halaman Mulai / AR uang

Tabel 5 Pengujian Halaman Mulai

\begin{tabular}{|l|l|l|c|}
\hline No. & \multicolumn{1}{|c|}{ Pengujian } & \multicolumn{1}{|c|}{ Hasil yang diharapkan } & Hasil Pengujian \\
\hline 1 & Uji tombol Muat Ulang & $\begin{array}{l}\text { Menampilkan kembali } \\
\text { kamera AR }\end{array}$ & Valid \\
\hline 2 & Uji Tombol Putar & $\begin{array}{l}\text { Suara } \\
\text { dihidupkan/dimatikan }\end{array}$ & Valid \\
\hline 3 & Uji Tombol Kembali & $\begin{array}{l}\text { Halaman Menu Utama } \\
\text { ditampilkan }\end{array}$ & Valid \\
\hline 4 & Uji Kamera AR & $\begin{array}{l}\text { Mengeluarkan AR yang } \\
\text { terdeteksi oleh marker }\end{array}$ & Valid \\
\hline
\end{tabular}

\section{b. Beta ( Kuisioner )}

Pengujian system yang dilakukan dengan metode skala likert, untuk mengukur semua kajian atribut oleh pengguna.

Tabel 6 Hasil Kuisioner

\begin{tabular}{|l|l|l|l|l|l|l|}
\hline No & \multicolumn{1}{|c|}{ Pertanyaan } & \multicolumn{3}{|c|}{ Persentase (\%) } \\
\cline { 3 - 7 } & & STS & TS & S & SS \\
\hline 1. & $\begin{array}{l}\text { Informasi yang disediakan oleh aplikasi ini mudah di } \\
\text { mengerti }\end{array}$ & 0 & 0 & 10 & 10 \\
\hline 2. & $\begin{array}{l}\text { Penggunaan menu atau fitur aplikasi menu mudah di } \\
\text { gunakan }\end{array}$ & 0 & 0 & 5 & 15 \\
\hline 3. & Aplikasi ini bermanfaat bagi pengguna & 0 & 0 & 12 & 8 \\
\hline 4. & $\begin{array}{l}\text { Aplikasi mempunyai kemampuan dan fungsi sesuai } \\
\text { yang di harapkan }\end{array}$ & 0 & 0 & 9 & 11 \\
\hline 5. & $\begin{array}{l}\text { Pembelajaran dengan menggunakan media lebih } \\
\text { menyenangkan disbanding hanya dengan metode } \\
\text { ceramah }\end{array}$ & 0 & 0 & 7 & 13 \\
\hline \multicolumn{4}{|l|}{ Jumlah Responden } & \multicolumn{5}{|c|}{20} \\
\hline
\end{tabular}

Keterangan :

1. Jumlah Pernyataan

- $\quad$ Sangat Tidak Setuju $=0$

- $\quad$ Tidak Setuju $=0$

- $\quad$ Setuju $=43$

- $\quad$ Sangat Setuju $=57$

Total $=100$

2. Jumlah Responden $=20$ Responden

- Hitung setiap row pernyataan kemudian pernyataan dijumlahkan.

- Lakukan Perhitungan.

a. Sangat Tidak Setuju

$$
\frac{0}{100} \times 100 \%=0 \%
$$

b. Tidak Setuju 


$$
\frac{0}{100} \times 100 \%=0 \%
$$

c. Setuju

$$
\frac{43}{100} \times 100 \%=43 \%
$$

d. Sangat Setuju

$$
\frac{57}{100} \times 100 \%=57 \%
$$

\section{KESIMPULAN}

Aplikasi yang di bangun telah dapat memberikan informasi yang lebih menarik dengan menambhakan animasi 3D serta suara. Media pembelajaran yang masih menggunakan buku cetak diubah menjadi media pembelajaran virtual yang menggunakan teknologi augmented reality, sehingga menjadi media pembelajaran yang menarik. Berdasarkan hasil kuesioner menunjukkan hasil Sangat Tidak Setuju 0\%, Tidak Setuju 0\%, Setuju 43\%, dan Sangat Setuju 57\%. Hasil ini menunjukkan aplikasi dinyatakan baik dan layak digunakan.

\section{REFERENSI}

[1] I. R. Ariani dan I. Renaldyansyah, "Historia: Media Pembelajaran Interaktif Berbasis Teknologi Realitas Tertambah Menggunakan Uang Kertas Rupiah Untuk Memperingati Sejarah Dan ...," eProceedings Appl. Sci., vol. 5, no. 2, hal. 1819-1824, 2019.

[2] H. Anra, P. Studi, T. Informatika, dan U. Tanjungpura, "Rancang Bangun Aplikasi Augmented Reality Berbasis Android Untuk Pengenalan Rumah Adat,” vol. 5, no. 4, hal. 163-169, 2017.

[3] T. K. Huang, C. H. Yang, Y. H. Hsieh, J. C. Wang, dan C. C. Hung, "Augmented reality (AR) and virtual reality (VR) applied in dentistry,” Kaohsiung J. Med. Sci., vol. 34, no. 4, hal. 243-248, 2018, doi: 10.1016/j.kjms.2018.01.009.

[4] E. Setiawan, U. Syaripudin, dan Y. A. Gerhana, "Implementasi Teknologi Augmented Reality pada Buku Panduan Wudhu Berbasis Mobile Android," J. Online Inform., vol. 1, no. 1, hal. 28, 2016, doi: 10.15575/join.v1i1.8.

[5] D. Amin dan S. Govilkar, "Comparative Study of Augmented Reality Sdk's," Int. J. Comput. Sci. Appl., vol. 5, no. 1, hal. 11-26, 2015, doi: 10.5121/ijcsa.2015.5102.

[6] S. Balandin, I. Oliver, S. Boldyrev, A. Smirnov, N. Shilov, dan A. Kashevnik, "Multimedia services on top of M3 Smart Spaces," Proc. - 2010 IEEE Reg. 8 Int. Conf. Comput. Technol. Electr. Electron. Eng. Sib., vol. 13, no. 2, hal. 728-732, 2010, doi: 10.1109/SIBIRCON.2010.5555154.

[7] M. H. N. Seto, T. Listyorini, dan A. Susanto, "Pengenalan Pahlawan Indonesia Berbasis Augmented Reality Dengan Marker Uang Indonesia,” Pros. SNATIF Ke-2, vol. 2, hal. 43-50, 2015.

[8] S. W. Sari, "Perkembangan Dan Pemikiran Uang Dari Masa Ke Masa," An-Nisbah J. Ekon. Syariah, vol. 3, no. 1, 2016, doi: 10.21274/an.2016.3.1.39-58.

[9] K. K. Budaya dan T. Samosir, "Culture is a way of life that developed and shared by a group of people, and inherited from one technology as a competitive sector that can added value to the business processes that run. The development of information and communication technology make,' Apl. EDUKASI BUDAYA TOBA SAMOSIR Berbas. ANDROID Harni, vol. 9, no. 1, hal. 9-18, 2016.

[10] N. Saurina, “Game Edukasi Sebagai Media Pembelajaran Untuk Kelas IV SDN Banjarsugihan II Menggunakan Blender 3D,” vol. 2, hal. 128-134, 2017. 
[11] I. Bagus dan M. Mahendra, "Implementasi Augmented Reality ( Ar ) Menggunakan Unity 3D Dan Vuporia Sdk," J. Ilm. ILMU Komput. Univ. Udayana, vol. 9, no. 1, hal. 1-5, 2016.

[12] J. W. Oak dan J. H. Bae, "Development of smart multiplatform game app using UNITY3D engine for CPR education," Int. J. Multimed. Ubiquitous Eng., vol. 9, no. 7, hal. 263-268, 2014, doi: 10.14257/ijmue.2014.9.7.22.

[13] A. Nugroho dan B. A. Pramono, “Aplikasi Mobile Augmented Reality Berbasis Vuforia Dan Unity Pada Pengenalan Objek 3D Dengan Studi Kasus Gedung M Universitas Semarang," J. Transform., vol. 14, no. 2, hal. 86, 2017, doi: 10.26623/transformatika.v14i2.442.

[14] X. Liu, Y.-H. Sohn, dan D.-W. Park, "Application development with vuforia and unity 3D," Int. J. Appl. Eng. Res., vol. 13, no. 21, hal. 43, 2018, [Daring]. Tersedia pada: https://www.ripublication.com/ijaer18/ijaerv13n21_33.pdf.

[15] A. F. Andikos, "Perancangan Aplikasi Multimedia Interaktif Sebagai Media Pembelajaran Pengenalan Hewan Pada Tk Islam Bakti 113 Koto Salak,” J. IJS, vol. 1, no. 1, hal. 34-49, 2019.

[16] D. Anggraeni dan S. Iriani, "Penerapan Sistem Inventory Sebagai Pemenuhan Kebutuhan Informasi Antar Bagian Berbasis Web Dengan Incremental Model,” Bianglala Inform. - Bianglala.bsi.ac.id, vol. 5, no. 2, hal. 1-7, 2017.

[17] D. Riana, R. Sanjaya, dan O. Kalsoem, "Sistem Informasi Manajemen Laboratorium Patologi Anatomi Menggunakan Model MVC Berbasis Laravel Framework,” Konf. Nas. Sist. Inf. 2018 STMIK Atma Luhur Pangkalpinang, 8 - 9 Maret 2018, hal. 8-9, 2018.

[18] Y. W. Arthana dan A. N. Ismail, "Perancangan Aplikasi Android Augmented Reality Media Pembelajaran Do'a Sehari-Hari,” Inf. (Jurnal Inform. dan Sist. Informasi), vol. 11, no. 1, hal. 18-45, 2019, doi: 10.37424/informasi.v11i1.8.

[19] S. Nidhra, "Black Box and White Box Testing Techniques - A Literature Review," Int. J. Embed. Syst. Appl., vol. 2, no. 2, hal. 29-50, 2012, doi: 10.5121/ijesa.2012.2204.

[20] M. S. Mustaqbal, R. F. Firdaus, dan H. Rahmadi, "PENGUJIAN APLIKASI MENGGUNAKAN BLACK BOX TESTING BOUNDARY VALUE ANALYSIS (Studi Kasus : Aplikasi Prediksi Kelulusan SNMPTN)," vol. I, no. 3, hal. 31-36, 2015. 